\title{
Tracing metabolic routes of dietary carbohydrate and protein in rainbow trout (Oncorhynchus mykiss) using stable isotopes $\left(\left[{ }^{13} \mathrm{C}\right]\right.$ starch and $\left[{ }^{15} \mathrm{~N}\right]$ protein): effects of gelatinisation of starches and sustained swimming
}

\author{
Olga Felip ${ }^{1,2 *}$, Antoni Ibarz ${ }^{1,2}$, Jaume Fernández-Borràs ${ }^{1,2}$, Marta Beltrán ${ }^{1,2}$, Miguel Martín-Pérez ${ }^{1,2}$, \\ Josep V. Planas ${ }^{1,2}$ and Josefina Blasco ${ }^{1,2}$ \\ ${ }^{1}$ Departament de Fisiologia, Facultat de Biologia, Universitat de Barcelona, Avinguda Diagonal 645, E-08028 \\ Barcelona, Spain \\ ${ }^{2}$ Xarxa de Referència de Recerca i Desenvolupament en Aqüicultura, Generalitat de Catalunya, Catalonia, Spain
}

(Received 14 March 2011 - Revised 7 June 2011 - Accepted 7 June 2011 - First published online 2 August 2011)

\begin{abstract}
Here we examined the use of stable isotopes, $\left[{ }^{13} \mathrm{C}\right]$ starch and $\left[{ }^{15} \mathrm{~N}\right]$ protein, as dietary tracers to study carbohydrate assimilation and distribution and protein utilisation, respectively, by rainbow trout (Oncorbynchus mykiss). The capacity of glucose uptake and use by tissues was studied, first, by varying the digestibility of carbohydrate-rich diets ( $30 \%$ carbohydrate), using raw starch and gelatinised starch (GS) and, second, by observing the effects of two regimens of activity (voluntary swimming, control; sustained swimming at 1.3 body lengths/s, exercise) on the GS diet. Isotopic ratio enrichment $\left({ }^{13} \mathrm{C}\right.$ and $\left.{ }^{15} \mathrm{~N}\right)$ of the various tissue components (protein, lipid and glycogen) was measured in the liver, muscles, viscera and the rest of the fish at 11 and $24 \mathrm{~h}$ after a forced meal. A level of $30 \%$ of digestible carbohydrates in the food exceeded the capacity of rainbow trout to use this nutrient, causing long-lasting hyperglycaemia that raises glucose uptake by tissues, and the synthesis of glycogen and lipid in liver. Total ${ }^{13} \mathrm{C}$ recovered $24 \mathrm{~h}$ post-feeding in the GS group was lower than at $11 \mathrm{~h}$, indicating a proportional increase in glucose oxidation, although the deposition of lipids in white muscle (WM) increased. Prolonged hyperglycaemia was prevented by exercise, since sustained swimming enhances the use of dietary carbohydrates, mainly through conversion to lipids in liver and oxidation in muscles, especially in red muscle (RM). Higher recoveries of total ${ }^{15} \mathrm{~N}$ for exercised fish at $24 \mathrm{~h}$, mainly into the protein fraction of both RM and WM, provide evidence that sustained swimming improves protein deposition, resulting in an enhancement of the protein-sparing effect.
\end{abstract}

Key words: $\delta^{13} \mathrm{C}$ and $\delta^{15} \mathrm{~N}$ : Carbohydrate: Protein: Sustained swimming

The capacity of rainbow trout (Oncorbynchus mykiss) to use dietary carbohydrates is controversial ${ }^{(1-3)}$, although several authors have claimed that diets with a high content of digestible starch $(20-30 \%)$ can stimulate growth ${ }^{(4,5)}$. However, while a protein-sparing effect from lipids has been reported in this species $^{(6-8)}$, there is no clear evidence that carbohydrates also have a protein-sparing effect. The replacement of fishmeal by plant ingredients is a common practice in aquaculture, even in carnivorous fish. Since plant sources contain large amounts of carbohydrates, the use of this alternative energy source is of interest. The physical state of the animal, the molecular complexity and the amount of starch in the diet influence carbohydrate digestibility and tolerance, and also the efficiency of fish growth. If the protein content of the diet is adequate, low levels of gelatinised starches promote growth in carnivorous fish, such as European eel (Anguilla anguilla $)^{(9)}$, cod (Gadus morbua) ${ }^{(10)}$, sturgeon (Acipenser transmontanus) ${ }^{(11)}$, Atlantic salmon (Salmo salar) ${ }^{(12,13)}$ and turbot (Scophthalmus maximus) ${ }^{(14)}$. As we have shown in brown trout, uptake and use of glucose by tissues depends on plasma glucose concentration ${ }^{(15)}$ and after an aortic glucose overload, almost all tissues increase glucose uptake. This is particularly true for skeletal muscle, which is the main target of the glucose load ${ }^{(16)}$. This effect may also be exerted by high levels of dietary carbohydrates, although, to our knowledge, this has not been measured experimentally.

Fish generally swim aerobically at submaximal velocities $^{(17-19)}$. Several fish species, when made to swim at about 1.3 body lengths/s (BL/s), show improved growth rate and food conversion efficiency ${ }^{(20)}$ through the increase of aerobic potential of red muscle (RM) and white muscle (WM). There is no general agreement on how metabolic fuels support aerobic

Abbreviations: at \%, atom percentage; BL/s, body lengths/s; GS, gelatinised starch; RM, red muscle; RS, raw starch; WM, white muscle. 
swimming in fish ${ }^{(21)}$. Protein and lipids were traditionally believed to be the main source of energy during sustained swimming in teleost fish, and carbohydrate utilisation was considered to be minimal $^{(22-26)}$. However, Alsop \& Wood $^{(27)}$ found that in satiation-fed rainbow trout, protein did not become more important as a fuel source during exercise. Further, Lauff \& Wood $^{(21)}$, using respirometric analyses, demonstrated that the most oxidised substrates during moderate swimming $\left(55-85 \% U_{\text {crit }}\right.$; critical swimming speed) were lipids, followed by carbohydrates, and then protein. Kieffer et $a l^{(28)}$ also found in rainbow trout that during swimming at 1 or $3 \mathrm{BL} / \mathrm{s}$, protein use decreased to $15 \%$ while the relative contribution of both lipid and carbohydrates increased. On the other hand, Shanghavi \& Weber ${ }^{(29)}$ noted that sustained swimming for a period of $3 \mathrm{~h}$ causes a $33 \%$ decline in hepatic glucose production, but plasma glucose levels are maintained stable by closely matching peripheral glucose utilisation. However, glucose disposal can also be conditioned by the source or type of diet, carbohydrate content, feeding regimen, gelatinisation process, etc. (reviewed by Hemre et $a l{ }^{(2)}$ ). Traditionally, studies on fish metabolism have used radioactive isotopes, but labelling feed ingredients with radioactive markers can be harmful to users and the aquatic environment. Stable isotopes are now used to study protein metabolism in fish. Thus, ${ }^{15} \mathrm{~N}$ has been administered orally to measure protein synthesis in species such as rainbow trout $(O . \text { mykiss })^{(30)}$, flounder (Pleuronectes flesus) ${ }^{(31)}$ or carp (Cyprinus carpio) ${ }^{(32)}$. In the present study, we used stable isotopes as dietary tracers $\left(\left[{ }^{13} \mathrm{C}\right]\right.$ starch and $\left[{ }^{15} \mathrm{~N}\right]$ protein $)$, as a preferred method for tracing dietary nutrient allocation in fish ${ }^{(33)}$, with the following two aims: (1) to measure the effects of gelatinisation of starch on $\left[{ }^{13} \mathrm{C}\right]$ glucose uptake and use by tissues in rainbow trout fed a carbohydrate-rich diet; (2) to determine the effects of sustained swimming on the efficiency of carbohydrate use in this species. To our knowledge, there are no studies on routing both carbohydrates and protein from $\left[{ }^{13} \mathrm{C}\right]$ starch and $\left[{ }^{15} \mathrm{~N}\right]$ protein added to the diet. This alternative method has allowed us to show improved assimilation and distribution of dietary carbohydrates, and their protein-sparing effect in rainbow trout under sustained swimming.

\section{Experimental methods}

\section{Experimental design and sampling}

Expt 1: effects of raw and gelatinised starch on glucose uptake by tissues of rainbow trout fed with carbohydrate-rich diets. Rainbow trout from a local fish farm (Truchas del Segre, Lleida, Spain) were held in the facilities of the Faculty of Biology (University of Barcelona, Barcelona, Spain) in 1000 litre tanks with fresh water within a semi-closed system ( $10 \%$ of water renovation daily) with physical and biological filters, ozone skimmers and continuous aeration at $15^{\circ} \mathrm{C}$ and a $12 \mathrm{~h}$ light $-12 \mathrm{~h}$ dark photoperiod. Fish with an average body weight of $180 \mathrm{~g}$ were randomly distributed into two experimental groups (twenty-five fish/tank), which were fed with two experimental diets with a high level of raw starch (RS) or gelatinised starch (GS) (see diet compositions given in Table 1). After 1 month, fourteen fish from each group were lightly anaesthetised and then force-fed a bolus, equivalent to $1 \%$ of body weight, with a gastric cannula. Fish were held in separated tanks for only a few minutes to check the acceptance of the forced meal. Any fish showing some degree of regurgitation was disqualified, and another one was used in its place. Fish were returned to their respective tanks and maintained for 11 or $24 \mathrm{~h}$ post-feeding. These two periods were chosen as they represent the postabsorption maximum (11 h) and nutrient use completion (24h) time points. Diets were labelled with 3\% $\left[{ }^{13} \mathrm{C}\right]$ starch $\left(\left[{ }^{13} \mathrm{C}\right]\right.$ algal starch; Martek Biosciences Corporation, Columbia, MD, USA). Another four animals from each group received the same dietary ration containing non-labelled starch, and they were used to measure the background level of ${ }^{13} \mathrm{C}$, to establish the natural abundance (i.e. blank value of each sample). At $11 \mathrm{~h}$ after the oral administration of the diets, half of the fish (seven fish fed the diets labelled with stable isotope plus two fish as blanks) were anaesthetised, killed by sectioning the spinal cord and sampled. Blood samples from the caudal vessel were centrifuged $(12000 \mathrm{~g}$, $5 \mathrm{~min}$ at $4^{\circ} \mathrm{C}$ ) to obtain plasma. Portions of the liver, and WM and RM and viscera (gut plus perivisceral fat) were excised, frozen in liquid $\mathrm{N}_{2}$ and stored at $-80^{\circ} \mathrm{C}$ until analysis, as were the rest of the fish and plasma samples. The entire sampling procedure took less than $3 \mathrm{~min}$ from the death of the fish, and the tissues with high glycogen hydrolytic capacity, such as muscle, were frozen first. After $24 \mathrm{~h}$ of forced-feeding, the remaining animals were sampled using the same protocol.

Table 1. Ingredients and chemical composition of the experimental diets

\begin{tabular}{lrr}
\hline & RS & GS \\
\hline Ingredients (\% DM) & & \\
Fishmeal CP70 & 59.10 & 59.10 \\
CPSP G & 5.00 & 5.00 \\
Crude wheat starch & 30.00 & 0.00 \\
Gelatinised wheat starch & 0.00 & 30.00 \\
Fish oil & 2.90 & 2.90 \\
Binder & 1.00 & 1.00 \\
Mineral premix* & 1.00 & 1.00 \\
Vitamin premixt & 1.00 & 1.00 \\
Proximate composition & & \\
Crude protein (\% DM) & 44.39 & 44.39 \\
Crude fat (\% DM) & 10.00 & 10.00 \\
Digestible protein (\% DM) & 39.16 & 39.16 \\
Digestible energy (kJ/g DM) & 14.67 & 16.82 \\
P (\% DM) & 1.77 & 1.77 \\
\hline
\end{tabular}

RS, raw starch; GS, gelatinised starch; CPSP G, fish soluble concentrate protein with high-fat level.

* Supplied the following $(\mathrm{mg} / \mathrm{kg}$ diet, except as noted): calcium carbonate $(40 \%$ Ca) $2.15 \mathrm{~g}$, magnesium hydroxide $(60 \% \mathrm{Mg}) 1.24 \mathrm{~g}$, potassium chloride $0.9 \mathrm{~g}$, ferric citrate $0.2 \mathrm{~g}$, potassium iodide $4 \mathrm{mg}, \mathrm{NaCl} 0.4 \mathrm{~g}$, calcium hydrogen phosphate $50 \mathrm{~g}$, copper sulphate 0.3 , zinc sulphate 40 , cobalt sulphate 2 , manganese sulphate 30 , sodium selenite 0.3 .

† Supplied the following ( $\mathrm{mg} / \mathrm{kg}$ diet): retinyl acetate 2.58 , DL-cholecalciferol 0.037 , DL- $\alpha$-tocopheryl acetate 30 , menadione sodium bisulphite 2.5 , thiamin 7.5 , riboflavin 15 , pyridoxine 7.5 , nicotinic acid 87.5 , folic acid 2.5 , calcium pantothenate 2.5 , vitamin $B_{12} 0.025$, ascorbic acid 250 , inositol 500 , biotin 1.25 , choline chloride 500 . 
Expt 2: effects of sustained swimming on the use of carbohydrates by rainbow trout. Juvenile rainbow trout (with an average weight of $60 \mathrm{~g}$ ) from the same fish farm were acclimatised indoors as in the previous experiment. For individual monitoring, sixty fish were identified with a passive integrated transponder (PIT) tag (Trovan Electronic Identification Systems, Madrid, Spain) near the dorsal fin, and were randomly distributed into four 200 litre circular tanks (fifteen fish/tank) at a density of $4 \mathrm{~kg} / \mathrm{m}^{3}$. Of these four tanks, two were kept on standard rearing conditions, with a water flow of 350 litres/h and vertical water inflow. Fish in these conditions presented only spontaneous movements (voluntary swimming) and were used as the control group. The other two tanks (exercise group) were kept in a circular, uniformly distributed flow of 700 litres/h, induced by the perpendicular water entrance at the surface and a submerged water pump at the bottom of the tank, isolated from the free-living area. The shape of the tank prevented the fish from entering a central area of lower velocity, thus guaranteeing similar swimming velocities throughout the experiment. Consequently, water volume and fish density were the same as in the control group. This design and water flow resulted in a swimming velocity of $1.3 \mathrm{BL} / \mathrm{s}$, measured and adjusted at three different tank depths (surface, mid-tank and near the bottom) using a low-speed mechanical flow meter (General Oceanics, Inc., Miami, FL, USA). All fish were kept in the same semi-closed circuit, guaranteeing that physico-chemical water parameters were the same for both groups, and they were fed twice a day to apparent satiety with the diet rich in digestible carbohydrates (GS) for 1 month (see diet composition given in Table 1). Feed intake was recorded daily for each tank and the specific growth rate $(100 \times(\ln$ final weight $-\ln$ initial weight)/d) and food conversion ratio (feed intake:wet bodyweight gain) were also calculated for each tank at the end of the experimental period. After 1 month, eighteen fish from the exercise group and twelve from the control group were lightly anaesthetised and force-fed with a gastric cannula a ration of $1 \%$ of diet labelled with $1 \%\left[{ }^{15} \mathrm{~N}\right]$ Spirulina protein and $3 \%\left[{ }^{13} \mathrm{C}\right]$ algal starch. From each group, two other fish received the same dietary ration containing similar proportions of non-labelled Spirulina protein and algal starch. These four fish were used to measure natural abundances of ${ }^{15} \mathrm{~N}$ and ${ }^{13} \mathrm{C}$ in samples (blank values). After force-feeding, fish were held for a few minutes in separate tanks as indicated for the first experiment. Then, fish were returned to their respective tanks and maintained for 11 or $24 \mathrm{~h}$ post-feeding (exercise group swam until the moment they were sampled). At $11 \mathrm{~h}$ after feeding, nine fish from the sustained swimming group and six from the control group were anaesthetised and killed by sectioning the spinal cord. Samples of blood were extracted from caudal vessels, and then, samples of liver, WM and RM, viscera (gut plus perivisceral fat) and the rest of the fish were rapidly excised, frozen in liquid $\mathrm{N}_{2}$ and stored at $-80^{\circ} \mathrm{C}$ until analysis. As in the first experiment, the entire sampling procedure took less than $3 \mathrm{~min}$ from the death of the fish, and the tissues with high glycogen hydrolytic capacity, such as muscle, were frozen first. The same procedure was repeated at $24 \mathrm{~h}$ post-feeding with the other nine and six fish from the sustained swimming and control groups, respectively. Although the initial body weight of rainbow trout differed between the two experiments, all fish can be considered as juvenile fish in a linear phase of growth. For the exercise trial, we used fish of $60 \mathrm{~g}$ constrained by the size and number of the tanks available for implementing sustained swimming.

Before conducting the animal trials, prior approval of the Comitè Ètic d'Experimentació Animal de la Universitat de Barcelona (CEEA-UB, Ethics Committee) was obtained. The specific ethics approval number for the protocol was CEEA-96/09.

\section{Plasma analysis and proximal composition of tissue samples}

Plasma was used to determine glucose concentration (Commercial Kit Glucofix, Menarini, Italy) based on the enzymatic method of glucose oxidase described by Werner et al. ${ }^{(34)}$. Tissue samples (liver, muscles and viscera) were homogenised in liquid $\mathrm{N}_{2}$ using a pestle and mortar to obtain a fine powder. The rest of the fish was homogenised at $-20^{\circ} \mathrm{C}$ using a food homogeniser (Pacojet AG, Zug, Switzerland). Samples were apportioned for the various analyses: percentage of lipids, proteins, glycogen and water determination, and one part of the sample was used for isotopic analysis. Tissue water content was determined gravimetrically after drying the samples at $100^{\circ} \mathrm{C}$ for more than $24 \mathrm{~h}$. Lipids were extracted as described by Folch et al. ${ }^{(35)}$. The washed lipid extracts were dried under a $\mathrm{N}_{2}$ atmosphere and the lipid content was determined gravimetrically. Protein was purified from defatted samples via precipitation with $10 \%(\mathrm{v} / \mathrm{v})$ trifluoroacetic acid. Protein extracts were dried by a vacuum system (Speed Vac Plus, AR, Savant Speed Vac Systems, South San Francisco, CA, USA) and protein content was calculated from $\mathrm{N}$ obtained by elemental analysis (Elemental Analyser Flash 1112, ThermoFinnigan, Bremen, Germany), assuming that $\mathrm{N}$ content is $1 \mathrm{~g}$ for every $6 \cdot 25 \mathrm{~g}$ of protein. Glycogen was extracted and purified by alcoholic precipitation after alkaline tissue hydrolysis with $30 \% \mathrm{KOH}$ in heat ${ }^{(36)}$. Glycogen content was analysed using the anthrone colorimetric method described by Fraga ${ }^{(37)}$.

\section{$\delta^{15} \mathrm{~N}$ and $\delta^{13} \mathrm{C}$ determination in tissues and expression of results}

The enrichments in ${ }^{13} \mathrm{C}$ were determined in both experiments, and the enrichments in ${ }^{15} \mathrm{~N}$ were measured in the second experiment. Dried samples of diets and tissues, as well as the purified lipid, glycogen and protein fractions of each tissue, were lyophilised and ground in a mortar to a homogeneous powder for isotope-ratio mass spectrometry analysis. Aliquots ranging from 0.3 to $0.6 \mathrm{mg}$ were accurately weighed in small tin capsules $(3.3 \times 5 \mathrm{~mm}$; Cromlab, Barcelona, Spain). Samples were analysed for $\mathrm{C}$ and $\mathrm{N}$ isotope composition using a Mat Delta $\mathrm{C}$ isotope-ratio mass spectrometry (Finnigan MAT, Bremen, Germany) coupled to an elemental analyser (Flash 1112) at Barcelona University 'Serveis Cientifico-Tècnics'. Isotope ratios $\left({ }^{15} \mathrm{~N} /{ }^{14} \mathrm{~N},{ }^{13} \mathrm{C} /{ }^{12} \mathrm{C}\right)$ are expressed 
on a relative scale as deviation, referred as $\delta$ units with the notation $\%$, parts per thousand, relative to the isotope ratio content of international standards: Pee Dee Belemnite (a calcium carbonate) for $\mathrm{C}$ and air for $\mathrm{N}$.

$\delta$ values were determined as follows:

$$
\delta=\left(\left(R_{\mathrm{sa}} / R_{\mathrm{st}}\right)-1\right) \times 1000,
$$

where $R_{\mathrm{sa}}={ }^{15} \mathrm{~N} /{ }^{14} \mathrm{~N}$ or ${ }^{13} \mathrm{C} /{ }^{12} \mathrm{C}$ of samples and $R_{\mathrm{st}}={ }^{15} \mathrm{~N} /{ }^{14} \mathrm{~N}$ or ${ }^{13} \mathrm{C} /{ }^{12} \mathrm{C}$ of standards. The same reference material analysed over the analysis period was measured with about $0.2 \%$ precision for natural materials and about $0.4 \% 0$ precision for enriched materials. The $\delta$ values are expressed as atom percentage (at \%) as follows:

$$
\begin{aligned}
& { }^{13} \mathrm{C} \text { at } \%=100 \times\left({ }^{13} \mathrm{C} /\left({ }^{13} \mathrm{C}+{ }^{12} \mathrm{C}\right)\right), \\
& { }^{15} \mathrm{~N} \text { at } \%=100 \times\left({ }^{15} \mathrm{~N} /\left({ }^{15} \mathrm{~N}+{ }^{14} \mathrm{~N}\right)\right) .
\end{aligned}
$$

The net enrichments (atom percentage excess) in ${ }^{13} \mathrm{C}$ and

${ }^{15} \mathrm{~N}$ of glycogen, lipid, protein and whole tissue were calculated by the difference between the atom percentage of samples and their corresponding blank values:

Atom percentage excess $=$ at $\%$ sample - at $\%$ blank.

Finally, using the values of atom percentage excess, molecular weight and Avogadro's number, the results are expressed as the percentage of marker in relation to the ingested dose ( $\mathrm{g} / 100 \mathrm{~g}{ }^{13} \mathrm{C}$ or ${ }^{15} \mathrm{~N}$ ingested) in each tissue fraction (glycogen, lipid and protein), which was calculated as follows:

$$
\begin{aligned}
& 100 \times\left(\left(g^{13} \mathrm{Cor}^{15} \mathrm{~N} / \mathrm{g} \text { t. fr. }\right) \times(\text { g t. fr. } / \text { g tissue })\right. \\
& \left.\times(\text { g tissue } / \text { g b.w. }) /\left(\text { g ingested }{ }^{13} \mathrm{C} \text { or }^{15} \mathrm{~N} / \mathrm{g} \text { b.w. }\right)\right)
\end{aligned}
$$

where t. fr. is the tissue fraction and b.w. is the body weight. The free pool of each tissue was calculated as the difference between isotope levels in the entire organ or tissue and the sum of the three tissue fractions. So, the measure in an entire organ, or tissue, represents the sum of all fractions (Eq. (1) + free pool) for ${ }^{13} \mathrm{C}$ or ${ }^{15} \mathrm{~N}$. In whole fish, it was calculated as the sum of all tissues (liver, WM and RM, viscera and the rest of the fish) for ${ }^{13} \mathrm{C}$ or ${ }^{15} \mathrm{~N}$.

For liver and viscera, the exact mass of the total tissue sample was measured by weighing the entire individual organs from the experimental fish. However, in order to estimate the total mass of WM and RM, we made accurate dissections of another ten fish under the same conditions as indicated earlier. The muscle-somatic index (g muscle/100 g body weight) obtained presented the values of $40 \%$ for WM and $4 \%$ for $\mathrm{RM}$.

\section{Statistics}

Results are presented as means with their standard errors. Unpaired $t$ tests were used to compare the two experimental groups at 11 and $24 \mathrm{~h}$, respectively, and in the two periods of the same condition. All statistical analyses were performed using SPSS version 14 (SPSS, Inc., Chicago, IL, USA).

\section{Results}

Expt 1: effects of raw and gelatinised starch on glucose uptake by tissues of rainbow trout fed with carbohydrate-rich diets

Plasma glucose levels and tissue proximal composition. The two forms of starch, RS and GS, in the diets are digested and absorbed at different rates, as reflected in the postprandial plasma glucose levels shown in Fig. 1. At $11 \mathrm{~h}$ after the meal, rainbow trout in the GS group presented plasma glucose levels 3-fold higher than the RS group (17 and $5.6 \mathrm{~mm}$, respectively). Although at $24 \mathrm{~h}$ after a meal, plasma glucose levels in the GS group decreased by $30 \%$, the hyperglycaemic situation was maintained $(10.3 \mathrm{~mm} ; P<0 \cdot 05)$. Higher amounts of assimilated carbohydrates also entailed 5-fold higher liver glycogen content in the GS group than in the RS group (GS, 10.28 (SEM 1.58)\% wet weight; RS, 2.02 (SEM 0.29)\% wet weight; $P<0 \cdot 05$ ), causing hypertrophy of the organ (hepatosomatic index: GS, 1.82 (SEM 0.09)\% wet weight; RS, 1.29 (SEM $0.03) \%$ wet weight; $P<0.05$ ) and a concomitant reduction of the other tissue components (lipid: GS, $2 \cdot 7$ (SEM 0.2) \% wet weight; RS, 4.3 (SEM 0.12) \% wet weight; $P<0.05$; protein: GS, $11 \cdot 2$ (SEM 0.3) \% wet weight; RS, $16 \cdot 2$ (sEM 0.4) \% wet weight; $P<0.05)$.

$\delta^{13} \mathrm{C}$ taken up by tissues. The total recovery of ${ }^{13} \mathrm{C}$ from whole fish and entire organs is shown in Fig. 2. Changes in this variable paralleled those observed in plasma glucose. Thus, while there were no differences in the RS group in the ${ }^{13} \mathrm{C}$ recovered between 11 and $24 \mathrm{~h}$ (18 and $22 \%$, respectively), higher levels were recovered in the GS group at $11 \mathrm{~h}$ (28\%), with a marked decrease at $24 \mathrm{~h}(18 \%)$. The uptake of ${ }^{13} \mathrm{C}$ in $\mathrm{RM}$ and WM increased from 11 to $24 \mathrm{~h}$ post-feeding in both groups. Thus, in the RS group, ${ }^{13} \mathrm{C}$ increased by $60 \%$ in $\mathrm{RM}$ and $78 \%$ in WM, and in the GS group, it increased

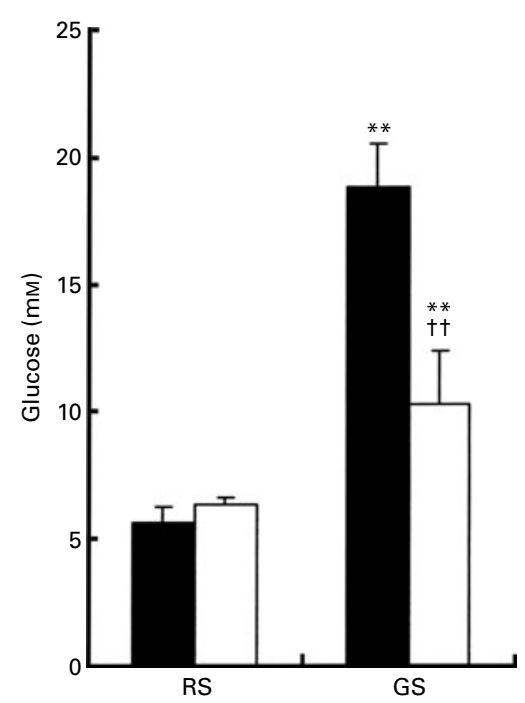

Fig. 1. Plasma glucose concentration $(\mathrm{mm})$ in rainbow trout fed with the raw starch (RS) and gelatinised starch (GS) diets, 11 ( $\square$ ) and $24 \mathrm{~h}(\square)$ after force-feeding. Values are means, with their standard errors represented by vertical bars $(n 9)$. ${ }^{\star *}$ Mean values were significantly different between the RS and GS groups $(P<0.01)$. †† Mean values were significantly different between 11 and $24 \mathrm{~h}(P<0.01)$. 


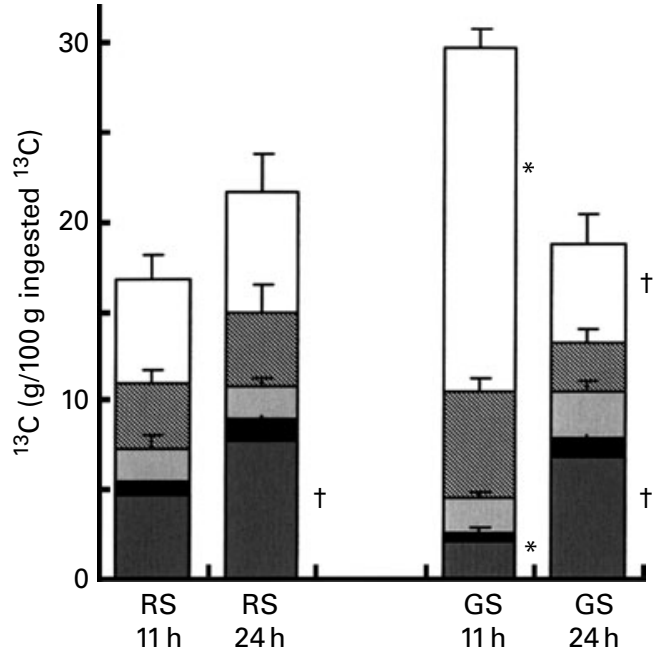

Fig. 2. Recovery of ${ }^{13} \mathrm{C}$ (as a percentage of ingested isotope) from entire organs or tissues (WM ( $\square$ ), white muscle; RM $(\square)$, red muscle; $L(\square)$, liver; $V(\mathbb{\mathbb { N }})$, viscera; $R(\square)$, the rest of the fish) of rainbow trout fed with the raw starch (RS) and gelatinised starch (GS) diets, 11 and $24 \mathrm{~h}$ after force-feeding. The sum of the stacked bar represents the total recovery from whole fish (see the Experimental methods section for details of the calculations). Values are means, with their standard errors represented by vertical bars $(n 7)$. * Mean values were significantly different between the RS and GS groups $(P<0.05)$. †Mean values were significantly different between 11 and $24 \mathrm{~h}$ $(P<0.05)$.

by $175 \%$ in $\mathrm{RM}$ and $100 \%$ in WM. Taking into account the total muscle mass of rainbow trout, more than $40 \%$ of body weight, the ${ }^{13} \mathrm{C}$ taken up by muscles was the main allocation site of the dietary $\left[{ }^{13} \mathrm{C}\right]$ starch $\left(43 \%\right.$ of the ${ }^{13} \mathrm{C}$ ingested was recovered in the RS group and $41 \%$ in the GS group).

The comparison of the values of ${ }^{13} \mathrm{C}$ recovered in each tissue fraction (protein, lipid and glycogen) in liver and WM is shown in Fig. 3. There were clear differences between the two diets in the fate of nutrients. The highest amount of ${ }^{13} \mathrm{C}$ in the liver of the RS group was found in protein $36 \%$ of total) and in glycogen (32\%), with only $8 \%$ in lipids. In the GS group, the highest labelled fraction in liver was lipids (27\% of total), then glycogen (19\%) and protein (12\%) (Fig. 3(a)). In WM, the levels of ${ }^{13} \mathrm{C}$ recovered in protein and lipid components of the GS group increased significantly between 11 and $24 \mathrm{~h}$ post-feeding (Fig. 3(b)). The incorporation of ${ }^{13} \mathrm{C}$ from dietary starch to muscle glycogen is shown in Fig. 4. No differences were found between the diets, although there was a significant correlation between ${ }^{13} \mathrm{C}$ levels in glycogen and the amount of glycogen present in RM $(r 0.84, P<0.01)$ and WM $(r 0.94, P<0.001)$, where ${ }^{13} \mathrm{C}$ deposition in glycogen in RM was 9-fold higher than that in WM.

\section{Expt 2: effects of sustained swimming on the use of carbohydrates by trout}

Food intake, fish growth, plasma glucose levels and tissue proximal composition. Sustained swimming caused a significant increase in food intake (control, 2.54 (SEM 0.14)\% body weight; exercise, 3.09 (SEM 0.15 ) \% body weight; $P<0.05$ ), reflecting higher metabolic costs but without impairing growth (specific growth rate: control, $2 \cdot 24$ (SEM 0.34) \% body weight/d; exercise, 2.63 (SEM 0.03) \% body weight). The food conversion ratio did not change significantly (control, 1.32 (sEm 0.37); exercise, 1.36 (SEM 0.11)). Under exercise, plasma glucose levels increased at $11 \mathrm{~h}$ after feeding $(P<0.05)$, but decreased significantly with respect to the control group at 24 h (Fig. 5).

Proximate composition of liver, RM and WM, at both 11 and $24 \mathrm{~h}$ post-feeding, is shown in Table 2 . Exercise modified liver composition due to a transient increase in glycogen content at $11 \mathrm{~h}$ and lipid mobilisation at $24 \mathrm{~h}$ post-feeding. Fish under exercise increased the glycogen content in RM and the lipid content in WM.

$\delta^{13} \mathrm{C}$ and $\delta^{15} \mathrm{~N}$ taken up by tissues. The recoveries of ${ }^{13} \mathrm{C}$ in glycogen, lipid, protein and free pool in liver, and WM and RM are shown in Fig. 6. In liver, sustained swimming induced higher total recoveries of ${ }^{13} \mathrm{C}$ (2-fold) with respect to the control group at both 11 and $24 \mathrm{~h}$, also in parallel with plasma glucose changes. The higher recovery in the liver of the exercise group was due, in part, to significant depositions of ${ }^{13} \mathrm{C}$ in protein and lipid fractions at $11 \mathrm{~h}$ (4- and 5-fold higher, respectively) and in the free pool at $24 \mathrm{~h}$ (7-fold increase). In WM, sustained swimming induced a significantly higher recovery of ${ }^{13} \mathrm{C}(P<0 \cdot 05)$, especially due to the recovery in the free pool at $11 \mathrm{~h}$ post-feeding. The ${ }^{13} \mathrm{C}$ recovered in (a)

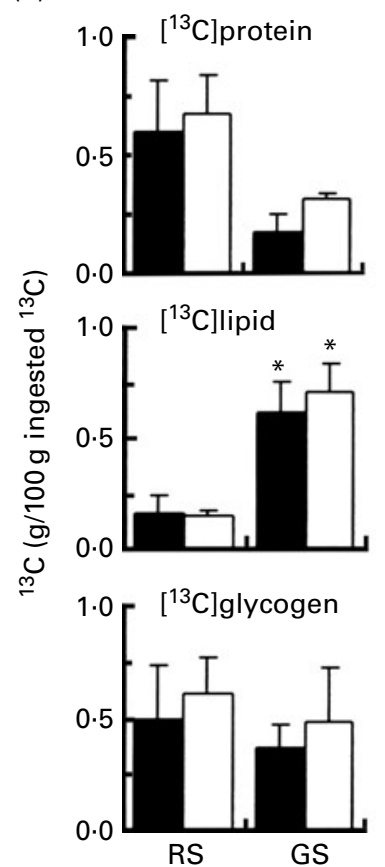

(b)
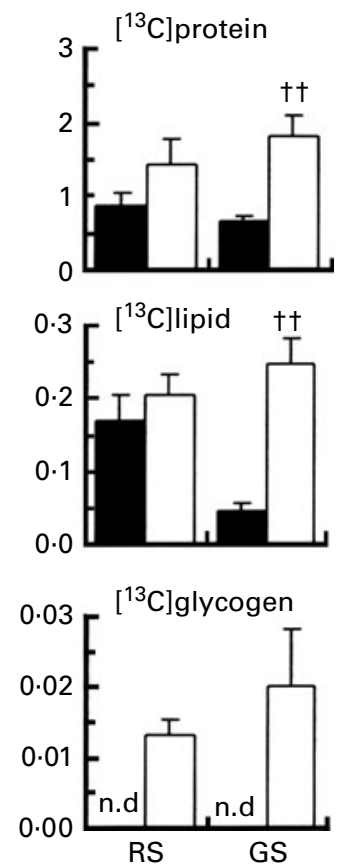

Fig. 3. Recovery of ${ }^{13} \mathrm{C}$ (as a percentage of ingested isotope) from (a) liver and (b) white muscle fractions (protein, lipid and glycogen) of rainbow trout

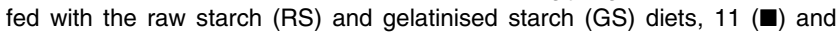
$24 \mathrm{~h}(\square)$ after force-feeding (see the Experimental methods section for details of the calculations). Recovery of ${ }^{13} \mathrm{C}$ from the glycogen fraction of white muscle was below the limit of detection (n.d., not detected). Values are means, with their standard errors represented by vertical bars $(n 7)$. * Mean values were significantly different between the RS and GS groups $(P<0.05)$. †† Mean values were significantly different between 11 and $24 \mathrm{~h}(P<0.01)$. 


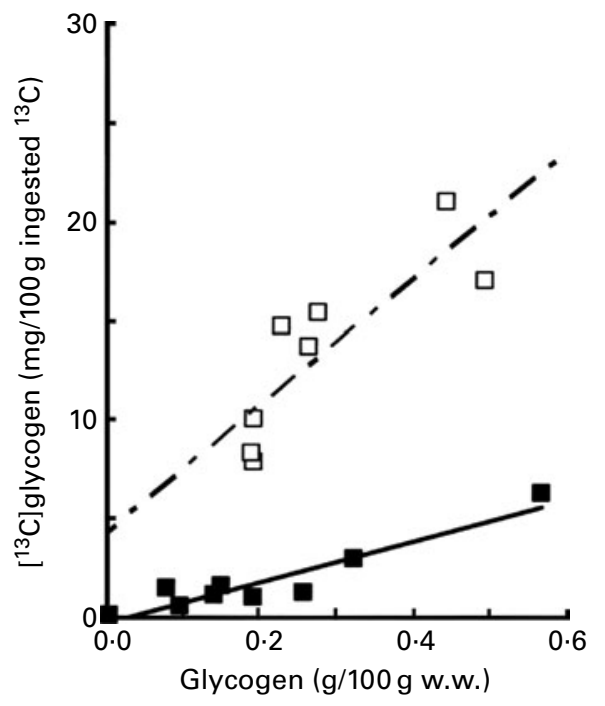

Fig. 4. Relationship between the glycogen content $(g / 100 \mathrm{~g}$ wet weight (w.w.)) and the percentage of $\left[{ }^{13} \mathrm{C}\right]$ glycogen recovered from dietary starch in white muscle $\left(\square ; y=10.315 x-0.2796, R^{2}=0.8829 ; P<0.001\right)$ and red muscle $\left(\square ; y=32.18 x+4.316, R^{2}=0.7049 ; P<0.01\right)$ of rainbow trout.

the protein fraction increased at $24 \mathrm{~h}(P<0.05)$ in both groups, but the incorporation of ${ }^{13} \mathrm{C}$ in the other tissue stores (lipid and glycogen) differed in the two groups. Thus, the control group significantly increased ${ }^{13} \mathrm{C}$ in glycogen (control, 95 (SEM 29) $v$. exercise, $2 \cdot 2$ (SEM $0 \cdot 3$ ) $\mathrm{mg}\left[{ }^{13} \mathrm{C}\right]$ glycogen $/ 100 \mathrm{~g}$ of ${ }^{13} \mathrm{C}$ ingested; $P<0 \cdot 05$ ), whereas in the exercise group higher deposition of ${ }^{13} \mathrm{C}$ in the lipid fraction was observed (control, 29 (SEM 12) $v$. exercise, 92 (sEM 16) $\mathrm{mg}\left[{ }^{13} \mathrm{C}\right]$ lipid/100 g of ${ }^{13} \mathrm{C}$ ingested; $P<0.05)$. In $\mathrm{RM}$, more than $85 \%$ of ${ }^{13} \mathrm{C}$ labelling was in the free pool, whereas depositions in protein and glycogen reserves were lower and no deposition was observed in lipids. However, the exercise group presented lower deposition of ${ }^{13} \mathrm{C}$ in the glycogen fraction than that of the control group.

The recoveries of ${ }^{15} \mathrm{~N}$ in protein and the free pool fractions of liver, and WM and RM are shown in Fig. 7. Sustained swimming did not modify the ${ }^{15} \mathrm{~N}$ recovery in liver, and the fate of ${ }^{15} \mathrm{~N}$ from dietary protein revealed the same pattern in WM and RM. The greatest recovery of total ${ }^{15} \mathrm{~N}$, due to the higher recovery in the protein fraction, occurred at $24 \mathrm{~h}$ in both muscles of the exercise group $(P<0.05)$.

As a summary of all results, Fig. 8(a) and (b) presents the total recoveries of ${ }^{13} \mathrm{C}$ and ${ }^{15} \mathrm{~N}$, respectively, after a single forced meal, including all tissues and fractions. The high ${ }^{13} \mathrm{C}$ recovery in whole fish under exercise, although not significantly different than that of the control group at $11 \mathrm{~h}$, decreased significantly between 11 and $24 \mathrm{~h}$. At $24 \mathrm{~h}$, the total ${ }^{15} \mathrm{~N}$ recovered in whole fish of the exercise group was significantly higher.

\section{Discussion}

For the first time, two stable isotopes $\left(\left[{ }^{13} \mathrm{C}\right]\right.$ starch and $\left[{ }^{15} \mathrm{~N}\right]$ protein) have been incorporated into fish diets as labels to study the fate of both nutrients in a species of reference, the rainbow trout. The use of $\left[{ }^{13} \mathrm{C}\right] \mathrm{starch}$ allowed us to analyse the distribution of dietary carbohydrates depending on the degree of gelatinisation. However, we should point out two limitations with this method that reduces its value for the assessment of the use of $\left[{ }^{13} \mathrm{C}\right]$ starch: the amount of label lost with the undigested food and the small amount of glucose lost via the urine in fish with the highest glycaemia $^{(15,38)}$. The long-lasting hyperglycaemia observed in the group fed the GS diet indicates higher absorption of carbohydrates in this group than in those fed RS. The digestibility of the two diets was not analysed in the present study, but we assume that the theoretical values of $58 \%$ for RS and $90 \%$ for GS are correct (see Brauge et $a l^{(39)}$ and Kaushik et al. ${ }^{(40)}$ ). This assumption is consistent with the postprandial glucose levels measured. Long-lasting hyperglycaemia in trout was previously seen as a result of feeding a high-carbohydrate $\operatorname{diet}^{(41)}$ or of a high glucose dose administrated orally ${ }^{(16,42)}$. Many fish species correct hyperglycaemia following a highcarbohydrate meal less rapidly than endotherms ${ }^{(1,43,44)}$. Apart from the differences in body temperature and metabolic rate, another reason, at least in rainbow trout, is a persistent, high level of endogenous glucose production from the liver $^{(45)}$. Key enzymes of gluconeogenesis in this species are always highly expressed, independently of nutritional status $^{(46)}$. In the present study, fish fed GS took up much more glucose into tissues, as shown by their higher plasma glucose levels and higher total recovery of ${ }^{13} \mathrm{C}$ in tissues at $11 \mathrm{~h}$. These higher uptake rates could contribute to the marked reduction of plasma glucose levels at $24 \mathrm{~h}$ in this group. These results are consistent with our previous study showing that brown trout (Salmo trutta) after an aortic glucose load labelled with ${ }^{14} \mathrm{C}$ presented higher glucose uptake rates into tissues, in proportion to the hyperglycaemia ${ }^{(16)}$. In

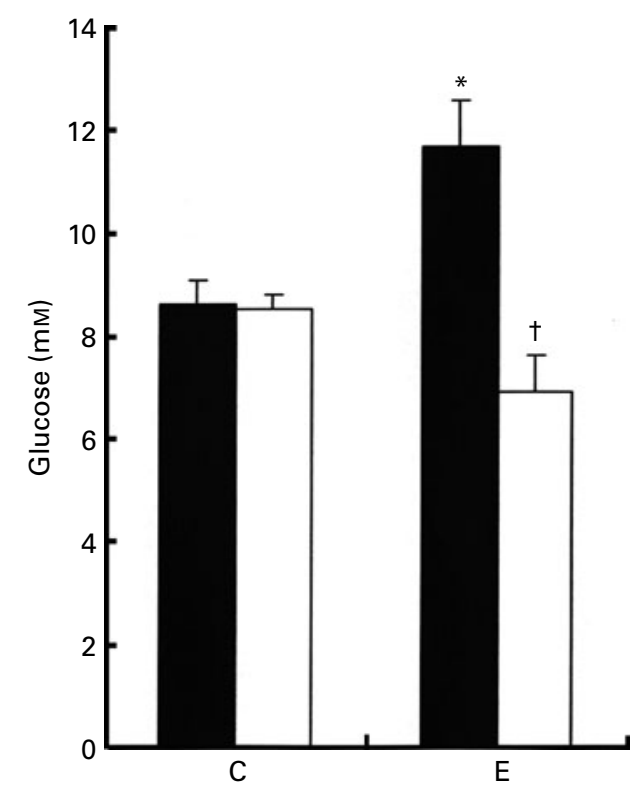

Fig. 5. Plasma glucose concentration $(\mathrm{mm})$ in rainbow trout subjected to sustained swimming (exercise, E) or to voluntary swimming (control, C), 11 $(\square)$ and $24 \mathrm{~h} \mathrm{( \square )}$ after force-feeding. Values are means, with their standard errors represented by vertical bars $(n 6, \mathrm{C})$ and $(n 9, \mathrm{E})$. * Mean values were significantly different between the two experimental groups $(P<0.05)$. † Mean values were significantly different between 11 and $24 \mathrm{~h}(P<0.05)$. 
Table 2. Proximal composition of liver and muscle in rainbow trout subjected to sustained swimming (Mean values with their standard errors, $n 6$ )

\begin{tabular}{|c|c|c|c|c|c|c|c|c|}
\hline & \multicolumn{4}{|c|}{$11 \mathrm{~h}$} & \multicolumn{4}{|c|}{$24 \mathrm{~h}$} \\
\hline & \multicolumn{2}{|c|}{ Control } & \multicolumn{2}{|c|}{ Exercise } & \multicolumn{2}{|c|}{ Control } & \multicolumn{2}{|c|}{ Exercise } \\
\hline & Mean & SEM & Mean & SEM & Mean & SEM & Mean & SEM \\
\hline \multicolumn{9}{|l|}{ Liver } \\
\hline $\mathrm{HSI}$ & $1 \cdot 8$ & $0 \cdot 11$ & $2 \cdot 1$ & 0.25 & 1.5 & 0.09 & $1 \cdot 8^{*}$ & 0.08 \\
\hline Liver glycogen (\% wet weight) & $5 \cdot 6$ & 0.54 & $10 \cdot 3^{*}$ & $1 \cdot 24$ & $5 \cdot 2$ & 0.90 & $7 \cdot 3$ & 0.58 \\
\hline Liver lipid (\% wet weight) & $4 \cdot 2$ & 0.09 & $4 \cdot 0$ & 0.11 & 4.4 & 0.18 & $3 \cdot 4^{*} \dagger$ & 0.13 \\
\hline Liver protein (\% wet weight) & $12 \cdot 8$ & 0.33 & $11 \cdot 3$ & 0.76 & $13 \cdot 8$ & 0.60 & $12 \cdot 4$ & 0.48 \\
\hline \multicolumn{9}{|l|}{ RM } \\
\hline RM glycogen (\% wet weight) & 0.68 & 0.09 & 1.00 & 0.11 & 0.52 & 0.04 & $0.77^{\star}$ & 0.06 \\
\hline RM lipid (\% wet weight) & $7 \cdot 2$ & 0.93 & $8 \cdot 1$ & 0.94 & $7 \cdot 2$ & 0.37 & $6 \cdot 6$ & 0.60 \\
\hline $\mathrm{RM}$ protein (\% wet weight) & $13 \cdot 4$ & 0.49 & $16 \cdot 5$ & 0.53 & $13 \cdot 3$ & 0.87 & $14 \cdot 4$ & 0.30 \\
\hline \multicolumn{9}{|l|}{ WM } \\
\hline WM glycogen (\% wet weight) & 0.13 & 0.03 & 0.08 & 0.01 & 0.28 & $0 \cdot 10$ & 0.07 & 0.01 \\
\hline WM lipid (\% wet weight) & 2.04 & 0.30 & $2 \cdot 88$ & 0.39 & $1.03+$ & 0.3 & $3.49^{\star}$ & 0.43 \\
\hline WM protein (\% wet weight) & $17 \cdot 7$ & 0.42 & $17 \cdot 2$ & 0.32 & $18 \cdot 2$ & 0.22 & $17 \cdot 5$ & 0.23 \\
\hline
\end{tabular}

$\mathrm{HSI}$, hepatosomatic index; RM, red muscle; WM, white muscle.

* Mean values were significantly different between the two experimental groups $(P<0.05)$.

$\dagger$ Mean values were significantly different between 11 and $24 \mathrm{~h}(P<0.05)$.

the present study, the $\left[{ }^{13} \mathrm{C}\right]$ glucose dilution was different in the RS and GS groups due to the similar amount of tracer delivered and the different glycaemia observed. Since the percentage of total ${ }^{13} \mathrm{C}$ recovered in muscle (WM plus $\mathrm{RM}$ ) was similar in the two groups (nearly $40 \%$ of the total ${ }^{13} \mathrm{C}$ recovered), the total amount of glucose taken up by the GS group must have been higher than that by the RS group. These results also reinforce the idea that skeletal muscle of rainbow trout is the main peripheral site of glucose disposal, similarly to what was observed in $\operatorname{cod}^{(47)}$, Atlantic salmon ${ }^{(48)}$ and brown trout ${ }^{(16)}$. The ${ }^{13} \mathrm{C}$ deposition rate into glycogen depots in RM was nine times higher than in WM, in agreement with the different capacity of glycogen repletion of each kind of muscle in exercised rainbow trout ${ }^{(49)}$. So, the importance of WM as the main site of glucose disposal cannot be overlooked, based on the large relative mass of the tissue. Higher carbohydrate uptake by the muscles of the GS group caused a proportional increase in ${ }^{13} \mathrm{C}$ recovered in all muscle reserves, especially in protein and lipid, in agreement with the results observed in brown trout after an aortic glucose load ${ }^{(16)}$. In rainbow trout, high dietary levels of digestible carbohydrates increased hepatic lipid content ${ }^{(50)}$, suggesting hepatic lipogenesis from carbohydrates ${ }^{(51)}$. In accordance with these studies, the present results show that higher glucose uptake in the liver of the GS group produced an increase of the glycogen depots (observed after 1 month of the GS diet) and the de novo synthesis of lipids in the liver. In the present study, nearly $20 \%$ of the total ${ }^{13} \mathrm{C}$ ingested was recovered at $24 \mathrm{~h}$, whereas in Atlantic salmon, the ${ }^{14} \mathrm{C}$ recovered ranged between 13 and $15 \%{ }^{(48)}$. Differences in species and in methodological conditions (tracer, starch or glucose) might explain these discrepancies. Glucose oxidation can be calculated from the difference between ${ }^{13} \mathrm{C}$ ingested and ${ }^{13} \mathrm{C}$ recovered from the whole fish after $24 \mathrm{~h}$ post-feeding, (a)

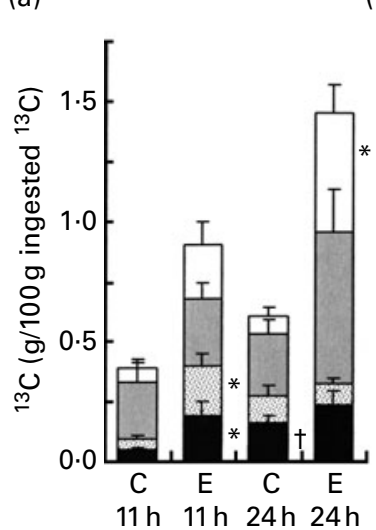

(b)

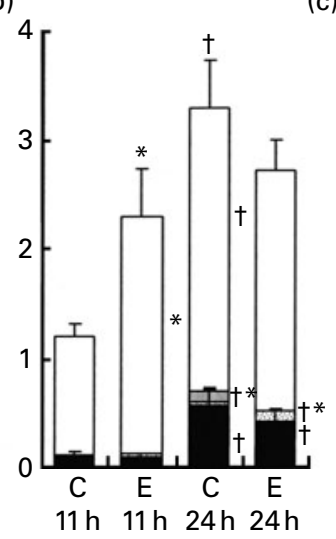

(c)

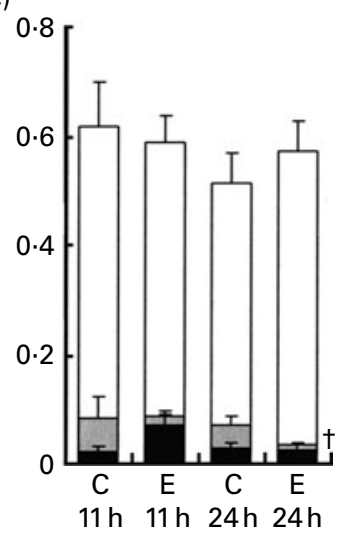

Fig. 6. Recovery of ${ }^{13} \mathrm{C}$ (as a percentage of ingested isotope) from (a) liver, (b) white muscle and (c) red muscle fractions (protein ( $\square$ ), lipid (圈), glycogen ( $\square$ ) and free pool $(\square)$ ) of rainbow trout subjected to sustained swimming (exercise, E) or to voluntary swimming (control, C), 11 and $24 \mathrm{~h}$ after force-feeding (see the Experimental methods section for details of the calculations). Values are means, with their standard errors represented by vertical bars $(n 6, \mathrm{C})$ and $(n 9, \mathrm{E})$. ${ }^{*}$ Mean values were significantly different between the two experimental groups $(P<0.05)$. † Mean values were significantly different between 11 and $24 \mathrm{~h}(P<0.05)$. 
(a)

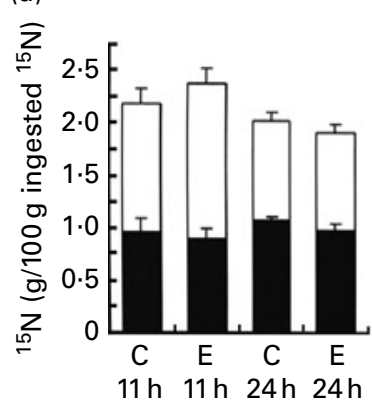

(b)

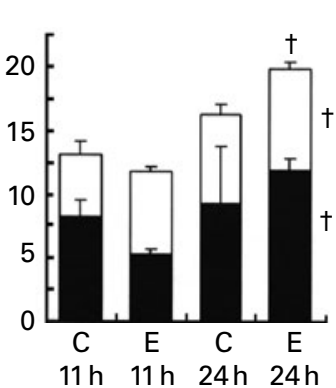

(c)

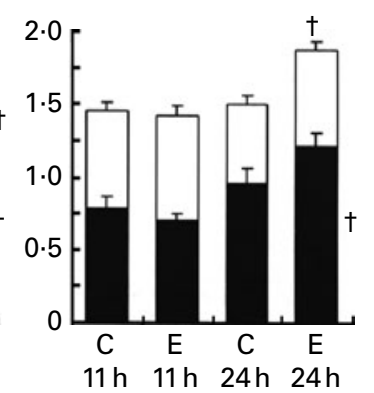

Fig. 7. Recovery of ${ }^{15} \mathrm{~N}$ (as a percentage of ingested isotope) from the protein ( $\square$ ) and free pool ( $\square$ ) fractions of the (a) liver, (b) white muscle and (c) red muscle of rainbow trout subjected to sustained swimming (exercise, E) or to voluntary swimming (control, C), 11 and $24 \mathrm{~h}$ after force-feeding (see the Experimental methods section for details of the calculations). Values are means, with their standard errors represented by vertical bars $\left(n 6\right.$, C) and $\left(n 9\right.$, E). ${ }^{\star}$ Mean values were significantly different between the two experimental groups $(P<0.05)$. $†$ Mean values were significantly different between 11 and $24 \mathrm{~h}(P<0.05)$.

but the values of $82 \%$ of glucose oxidised in the GS group and $77 \%$ in the RS group can be overestimates of the actual values due to the losses indicated before. The main issue, however, is that the measurement of ${ }^{13} \mathrm{C}$ in tissue stores confirms that excess glucose promotes lipogenesis, leading to significantly higher depots of newly formed, saturated fat in liver and muscle, even in trout accustomed to this diet.

Summarising all the results of the first experiment, gelatinisation of starch improved the absorption of dietary carbohydrates, causing a long-lasting hyperglycaemia, and glucose uptake by tissues rose in proportion to the plasma glucose concentrations in the post-absorptive period. This higher rate of glucose uptake by tissues favoured the synthesis of lipid in the liver. A level of $30 \%$ digestible carbohydrates fed daily, however, exceeds the capacities of rainbow trout to use this nutrient, as reflected in the hyperglycaemia maintained after $24 \mathrm{~h}$ and the deposition of lipids in WM. Consequently, if these lipids are not consumed as energy fuel, they will be deposited as saturated fat, which in excess can affect the fish fillet quality. This can be prevented by increasing energy expenditure through the induction of exercise. In the second experiment, only the GS diet was used to determine the effects of moderate, sustained swimming on the use of nutrients as energy fuels. The swimming regimen of $1.3 \mathrm{BL} / \mathrm{s}$ for 1 month was used as a 'metabolic promoter'. In this situation of induced activity, rainbow trout increased feed intake to compensate for the higher energy costs due to the exercise. Although Davison \& Goldspink ${ }^{(52)}$ found an increase of food conversion ratio in exercised brown trout fed chopped liver, no significant differences were observed between the groups in the present study, perhaps due to the dietary differences. Rainbow trout growth rate showed a tendency to increase in exercise, in agreement with the results reported by Houlihan \& Laurent ${ }^{(53)}$ and Farrell et al. ${ }^{(54)}$.

A carbohydrate-rich diet fed under exercise also induced transitory hyperglycaemia $11 \mathrm{~h}$ post-feeding, but glycaemia returned to control values at $24 \mathrm{~h}$. This transitory hyperglycaemia in the swimming group is attributed to higher food ingestion. As indicated before, the maintenance of hepatic gluconeogenesis in rainbow trout feeding carbohydrate-rich diets $^{(45,55)}$ can contribute to hyperglycaemia. As observed in the first experiment, hyperglycaemia raised glucose uptake rates in liver and WM. Thus, in liver, the total recovery of ${ }^{13} \mathrm{C}$ was 2 -fold higher in the exercise group, indicating greater
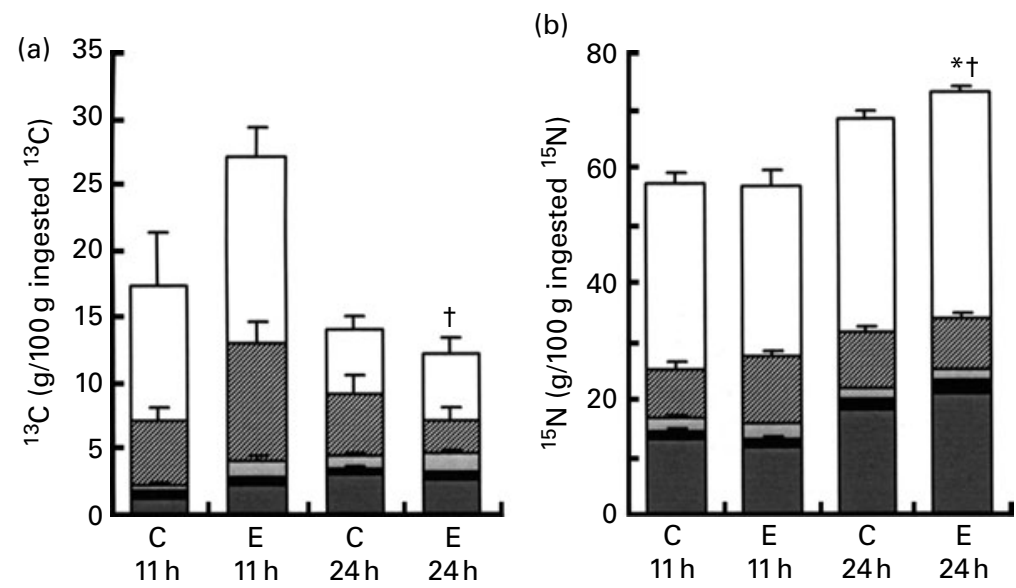

Fig. 8. Recovery of (a) ${ }^{13} \mathrm{C}$ and (b) ${ }^{15} \mathrm{~N}$ (as a percentage of ingested isotope) from entire organs or tissues (WM ( $\square$ ), white muscle; RM ( $\square$ ), red muscle; $L$ ( $\square$ ), liver; $V(\mathbb{\mathbb { N }})$, viscera; $R(\square)$, the rest of the fish) of rainbow trout subjected to sustained swimming (exercise, E) or to voluntary swimming (control, $C$ ), 11 and $24 \mathrm{~h}$ after force-feeding. The sum of the stacked bar represents the total recovery from whole fish (see the Experimental methods section for details of the calculations). Values are means, with their standard errors represented by vertical bars $(n 6, \mathrm{C})$ and $\left(n 9\right.$, E). ${ }^{*}$ Mean values were significantly different between the $\mathrm{E}$ and $\mathrm{C}$ groups $(P<0.05)$. † Mean values were significantly different between 11 and $24 \mathrm{~h}(P<0.05)$. 
uptake and deposition into the various tissue reserves. The postprandial variation of glycogen content, related to glycaemia, was evidence of higher carbohydrate uptake and use in exercised fish than in controls. Moreover, hepatic lipogenesis from dietary carbohydrates was also enhanced and, combined with the lower level of liver fat in the exercise group at the end of the experiment, this observation supports the idea of higher mobilisation of hepatic lipids to extrahepatic tissues. The increase in muscle lipid content in the exercised rainbow trout, in agreement with the increase in muscle lipid content found in several fish species under exercise conditions ${ }^{(52,56,57)}$, should in part be caused by such mobilisation. Fish rely mainly on fatty acids to fuel submaximal exercise ${ }^{(28)}$, mediated by an enhancement of lipoprotein lipase activity in $\mathrm{RM}^{(58)}$. However, the origin of these lipids has not been traced previously. The addition of $\left[{ }^{13} \mathrm{C}\right]$ algal starch to the diet enabled us to ensure that lipid synthesised de novo in the liver is mobilised and transported to skeletal muscles and oxidised or used to replenish stores. The present results on the lack of ${ }^{13} \mathrm{C}$ in the lipid fraction of $\mathrm{RM}$ support the notion that lipids are highly used as aerobic energy fuel by this tissue, as reported by Magnoni \& Weber ${ }^{(58)}$. On the other hand, the balance in WM results in a net lipid deposition. Additional information can be drawn from high levels of ${ }^{13} \mathrm{C}$ recovered in the free pool of RM. This labelling corresponds to several kinds of molecules of the intermediary metabolism and is indicative of the higher metabolic activity of RM. During moderate and sustained swimming, RM burns not only fatty acids provided by the liver, but also glycogen. The present results support that dietary carbohydrates play a key role in muscle metabolism during exercise. Moreover, West et al. ${ }^{(59)}$ reported a 30 -fold rise in glucose use by RM in rainbow trout under a steady swimming speed at $80 \% U_{\text {crit }}$.

Non-protein energy sources spare dietary protein from oxidation as fuel, thus releasing it for growth. Thus, high protein efficiency ratios in rainbow trout fed diets containing about $30 \%$ of digestible carbohydrates have been reported ${ }^{(4,60)}$. In the present study, the use of $\left[{ }^{15} \mathrm{~N}\right]$ protein as a dietary tracer allowed us to measure the amount of protein allocated to the main tissues following a single meal. Houlihan \& Laurent ${ }^{(53)}$ reported that both protein synthesis and protein degradation increased in exercised rainbow trout, leading to increased growth rate. In the present study, the greatest recovery of total ${ }^{15} \mathrm{~N}$ for exercised fish at $24 \mathrm{~h}$, mainly in the protein fraction of RM and WM, is evidence that exercise improves protein deposition. Exercise may also reduce $\mathrm{N}$ wastes. In conclusion, one forced-feeding with labelled nutrients, $\left[{ }^{13} \mathrm{C}\right]$ starch and $\left[{ }^{15} \mathrm{~N}\right]$ protein, has allowed us to show that sustained swimming in rainbow trout improves the use of digestible carbohydrates and of lipid and glycogen depots, resulting in an enhancement of the protein-sparing effect.

\section{Acknowledgements}

We thank Dr F. Medale (INRA, St Pee) for providing the experimental diets. The present study was supported by grants from the Catalan government and the Spanish government (AGL2002-03987 to J. V. P.). O. F. and M. M.-P. received fellowships from FPI-2007 and FI-2007 of the Spanish government and the Catalan government, respectively. The authors' responsibilities were as follows: J. F.-B., A. I., and J. B. planned the project. J. F.-B., A. I., J. B., O. F., M. B. and M. M.-P. carried out the experiment and collected the samples. O. F. carried out the laboratory analyses. O. F., A. I., J. F.-B., J. V. P. and J. B. carried out the data analysis and interpretation and $\mathrm{O}$. F and J. B. wrote the manuscript; all authors read and approved the final manuscript. The authors declare that they have no competing interests to report.

\section{References}

1. Wilson RP (1994) Utilization of dietary carbohydrate by fish. Aquaculture 124, 67-80.

2. Hemre GI, Mommsen TP \& Krogdahl A (2002) Carbohydrates in fish nutrition: effects on growth, glucose metabolism and hepatic enzymes. Aquac Nutr 8, 175-194.

3. Stone DAJ (2003) Dietary carbohydrate utilization by fish. Rev Fish Sci 11, 337-369.

4. Kim DJ \& Kaushik SJ (1992) Contribution of digestible energy from carbohydrates and estimation of protein/ energy requirements for growth of rainbow trout (Oncorhynchus mykiss). Aquaculture 106, 161-169.

5. Capilla E, Médale F, Navarro I, et al. (2003) Muscle insulin binding and plasma levels in relation to liver glucokinase activity, glucose metabolism and dietary carbohydrates in rainbow trout. Regul Pept 110, 123-132.

6. Beamish FWH \& Medland TE (1986) Protein sparing effects in large rainbow trout, Salmo gairdneri. Aquaculture $\mathbf{5 5}$, $35-42$.

7. Murai T (1992) Protein nutrition of rainbow trout. Aquaculture 100, 191-207.

8. Rasmussen RS, Ostenfeld TH \& McLean E (2000) Growth and feed utilisation of rainbow trout subjected to changes in feed lipid concentrations. Aquac Int 8, 531-542.

9. Degani G, Viola S \& Levanon D (1986) Effects of dietary carbohydrate source on growth and body composition of the European eel (Anguilla anguilla L.). Aquaculture 52, 97-104.

10. Hemre GI, Lie $\varnothing$, Lied E, et al. (1989) Starch as an energy source in feed for cod (Gadus morhua): digestibility and retention. Aquaculture 80, 261-270.

11. Hung SSO, Fynn-Aikins K, Lutes PB, et al. (1989) Ability of juvenile white sturgeon (Acipenser transmontanus) to utilize different carbohydrate sources. J Nutr 119, 727-733.

12. Hemre GI, Sandnes K, Lie $\varnothing$, et al. (1995) Carbohydrate nutrition in Atlantic salmon, Salmo salar L.: growth and feed utilization. Aquac Res 26, 149-154.

13. Hemre GI \& Hansen T (1998) Utilisation of different dietary starch sources and tolerance to glucose loading in Atlantic salmon (Salmo salar), during parr-smolt transformation. Aquaculture 161, 145-157.

14. Stephan G, Dreanno C, Guillaume J, et al. (1996) Incidence of different amounts of proteins, lipids and carbohydrates in diets on the muscle lipid composition in the turbot (Scophthalmus maximus). Ichtyophysiol Acta 19, 11-30.

15. Blasco J, Fernández J, Marimón I, et al. (1996) Plasma glucose kinetics and tissue uptake in vivo in brown trout. Effect of an intravascular glucose load. J Comp Physiol B 165, 534-541.

16. Blasco J, Marimón I, Viaplana I, et al. (2001) Fate of plasma glucose in tissues of brown trout in vivo: effects of fasting and glucose loading. Fish Physiol Biochem 24, 247-258. 
17. Weihs D (1973) Optimal fish cruising speed. Nature (London) 245, 48-50.

18. Beamish FWH (1978) Swimming capacity. In Fish Physiology, vol. VII Locomotion, Chapter 2. pp. 101-187 [WS Hoar and DJ Randall, editors]. New York: Academic Press.

19. Quinn TP (1987) Estimated swimming speeds of migrating adult sockeye salmon. Can J Zool 66, 2160-2163.

20. Davison W (1997) The effects of exercise training on teleost fish, a review of recent literature. Comp Biochem Physiol $A$ Mol Integr Physiol 117, 67-75.

21. Lauff RF \& Wood CM (1996) Respiratory gas exchange, nitrogenous waste excretion, and fuel usage during aerobic swimming in juvenile rainbow trout. J Comp Physiol B 166, 501-509.

22. Driedzic WR \& Hochachka PW (1978) Metabolism in fish during exercise. In Fish Physiology, vol. VII Locomotion, Chapter 8. pp. 503-543 [WS Hoar and DJ Randall, editors]. New York: Academic Press.

23. Walton MJ \& Cowey CB (1982) Aspects of intermediary metabolism in salmonid fish. Comp Biochem Physiol B Biochem Mol Biol 73, 59-79.

24. Van Waarde A (1983) Aerobic and anaerobic ammonia production by fish. Comp Biochem Physiol B Biochem Mol Biol 74, 675-684.

25. Jobling M (1994) Respiration and metabolism. In Fish Bioenergetics, part two, Chapter 8 [M Jobling, editor]. London: Chapman and Hall Fish and Fisheries Series 13.

26. Moyes CD \& West TG (1995) Exercise metabolism of fish. In Biochemistry and Molecular Biology of Fishes, vol. IV, Chapter 16, pp. 367-392 [PW Hochachka and TP Mommsen, editors]. Amsterdam: Elsevier.

27. Alsop DH \& Wood CM (1997) The interactive effects of feeding and exercise on oxygen consumption, swimming performance and protein usage in juvenile Rainbow trout (Oncorbynchus mykiss). J Exp Biol 200, 2337-2346.

28. Kieffer JD, Alsop D \& Wood CM (1998) A respirometric analysis of fuel use during aerobic swimming at different temperatures in rainbow trout (Oncorbynchus mykiss). J Exp Biol 201, 3123-3133.

29. Shanghavi DS \& Weber JM (1999) Effects of sustained swimming on hepatic glucose production of rainbow trout. $J$ Exp Biol 202, 2161-2166.

30. Carter CG, Owen SF, He ZY, et al. (1994) Determination of protein-synthesis in rainbow trout, Oncorbynchus mykiss, using a stable-isotope. J Exp Biol 189, 279-284.

31. Carter CG, Houlihan DF \& Owen SF (1998) Protein synthesis, nitrogen excretion and long-term growth of juvenile Pleuronectes flesus. J Fish Biol 53, 272-284.

32. Meyer-Burgdorff K \& Rosenow H (1995) Protein turnover and energy metabolism in growing carp 1. Method of determining N-turnover using a ${ }^{15} \mathrm{~N}$-labelled casein. J Anim Physiol Anim Nutr (Berl) 73, 113-122.

33. Beltrán M, Fernández-Borrás J, Médale F, et al. (2009) Natural abundance of ${ }^{15} \mathrm{~N}$ and ${ }^{13} \mathrm{C}$ in fish tissues and the use of stable isotopes as dietary protein tracers in rainbow trout and gilthead sea bream. Aquac Nutr 15, 9-18.

34. Werner W, Rey HG \& Wielinger H (1970) On the properties of a new chromogen for the determination of glucose in blood according to the GOD/POD-method. Z Analyt Chem 252, 224.

35. Folch J, Lees M \& Sloane Stanley GH (1957) A simple method for the isolation and purification of total lipides from animal tissues. J Biol Chem 226, 497-509.

36. Good BCA, Cramer H \& Somogy M (1933) The determination of glycogen. J Biol Chem 100, 491.
37. Fraga F (1956) Determination of glycogen in shellfish with the anthrone reagent (Determinación de glucógeno en moluscos con el reactivo de antrona). Investigaciones Pesqueras 3, 69.

38. Bucking C \& Wood CM (2005) Renal regulation of plasma glucose in the freshwater rainbow trout. J Exp Biol 208, 2731-2739.

39. Brauge C, Corraze G \& Médale F (1995) Effect of dietary levels of lipid and carbohydrate on growth-performance, body-composition, nitrogen-excretion and plasma-glucose levels in rainbow trout reared at 8-degrees-C or 18-degrees-C. Reprod Nutr Dev 35, 277-290.

40. Kaushik SJ, Médale F, Fauconneau B, et al. (1989) Effect of digestible carbohydrates on protein/energy utilization and on glucose metabolism in rainbow trout (Salmo gairdneri R.). Aquaculture 79, 63-74.

41. Bergot F (1979) Effects of dietary carbohydrates and of their mode of distribution on glycaemia in rainbow trout (Salmo gairdneri R.). Comp Biochem Physiol A Mol Integr Physiol 64, 543-547.

42. Palmer TN \& Ryman BE (1972) Studies on glucose intolerance in fish. J Fish Biol 4, 311-319.

43. Furuichi M \& Yone Y (1981) The utilization of carbohydrate by fishes. 3. Change of blood-sugar and plasma-insulin levels of fishes in glucose-tolerance test. Bull Jap Soc Scient Fish 47, 761-764.

44. Moon TW (2001) Glucose intolerance in teleost fish: fact or fiction? Comp Biochem Physiol B Biochem Mol Biol 129 , 243-249.

45. Enes P, Panserat S, Kaushik S, et al. (2009) Nutritional regulation of hepatic glucose metabolism in fish. Fish Physiol Biochem 35, 519-539.

46. Panserat S, Plagnes-Juan E \& Kaushik S (2001) Nutritional regulation and tissue specificity of gene expression for proteins involved in hepatic glucose metabolism in rainbow trout (Oncorbynchus mykiss). J Exp Biol 204, 2351-2360.

47. Hemre GI \& Kahrs F (1997) ${ }^{14}$ C-injection in Atlantic cod (Gadus morhua), metabolic responses and excretion via the gill membrane. Aquac Nutr 2, 3-8.

48. Hemre GI \& Storebakken T (2000) Tissue and organ distribution of ${ }^{14} \mathrm{dC}$-activity in dextrin-adapted Atlantic salmon after oral administration of radiolabelled ${ }^{14} \mathrm{C}_{1}$-glucose. Aquac Nutr 6, 229-234.

49. West TG, Schulte PM \& Hochachka PW (1994) Implications of hyperglycemia for post-exercise resynthesis of glycogen in trout skeletal muscle. J Exp Biol 189, 69-84.

50. Brauge C, Medale F \& Corraze G (1994) Effect of dietary carbohydrate levels on growth, body composition and glycaemia in rainbow trout, Oncorbynchus mykiss, reared in seawater. Aquaculture 123, 109-120.

51. Panserat S, Hortopan GA, Plagnes-Juan E, et al. (2009) Differential gene expression after total replacement of dietary fish meal and fish oil by plant products in rainbow trout (Oncorbynchus mykiss) liver. Aquaculture 294, 123-131.

52. Davison W \& Goldspink G (1977) The effect of prolonged exercise on the lateral musculature of the brown trout (Salmo trutta). J Exp Biol 70, 1-12.

53. Houlihan DF \& Laurent P (1987) Effects of exercise training on the performance, growth, and protein turnover of rainbow trout (Salmo gairdneri). Can J Fish Aquat Sci 44, $1614-1621$.

54. Farrell AP, Johansen JA, Steffensen JF, et al. (1990) Effects of exercise training and coronary ablation on swimming performance, heart size, and cardiac enzymes in rainbow trout, Oncorbynchus mykiss. Can J Zool 68, 1174-1179. 
55. Panserat S, Médale F, Blin C, et al. (2000) Hepatic glucokinase is induced by dietary carbohydrates in rainbow trout, gilthead sea bream, and common carp. Am J Physiol Regul Integr Comp Physiol 278, 1164-1170.

56. Totland GK, Kryvi H, Jødestøl KA, et al. (1987) Growth and composition of the swimming muscle of adult Atlantic salmon (Salmo salar L.) during long-term sustained swimming. Aquaculture 66, 299-313.

57. Yogata $\mathrm{H} \&$ Oku H (2000) The effects of swimming exercise on growth and whole-body protein and fat contents of fed and unfed fingerling yellowtail. Fish Sci 66, $1100-1105$

58. Magnoni L \& Weber JM (2007) Endurance swimming activates trout lipoprotein lipase: plasma lipids as a fuel for muscle. J Exp Biol 210, 4016-4023.

59. West TG, Arthur PG, Suarez RK, et al. (1993) In vivo utilization of glucose by heart and locomotory muscles of exercising rainbow trout (Oncorbynchus mykiss). J Exp Biol 177, 63-79.

60. Kaushik SJ \& Oliva Teles A (1985) Effect of digestible energy on nitrogen and energy balance in rainbow trout. Aquaculture 50, 89-101. 